Print ISSN: 2288-4637 / Online ISSN 2288-4645

doi:10.13106/jafeb.2020.vol7.no8.077

\title{
The Impact of Contingency Factors on Management Accounting Practices in Vietnam*
}

\author{
Duc Hieu PHAM${ }^{1}$, Thi Huong DAO ${ }^{2}$, Tien Dung BUI ${ }^{3}$
}

Received: June 03, 2020 Revised: June 14, 2020 Accepted: July 09, 2020

\begin{abstract}
The aim of this study is two-fold. Firstly, it attempts to assess the level of management accounting practices (MAPs) in manufacturing companies in Vietnam. Secondly, it purports to explore the impact of potential contingency factors on the current level of MAPs in the sample of studied companies from the industrial sector in Vietnam. The study examines the hypotheses that MAPs in Vietnamese manufacturing firms are affected by a range of contingent variables. A quantitative research was conducted by sending questionnaires to the target respondents that comprise both accountants and managers in 160 manufacturing enterprises in the north of Vietnam. The first main findings from the study reveal that MAPs in Vietnam are mainly traditional rather than contemporary ones, and oriented toward the shortterm rather than the long-term. The second main research findings resulted from multiple regression model show that MAPs in Vietnam are significantly affected by company size, commitment of directors, advanced manufacturing technology, and distinct number of products. However, no significant associations are found between MAPs and intensity of competition from the emerging market as hypothesized in this study. Research findings are bases for recommendations to promote the application of contemporary practices and enhance management accounting functions in manufacturing companies in Vietnam.
\end{abstract}

Keywords : Management Accounting, Management Accounting Practices (MAPs), Manufacturing, Contingency Factors, Vietnam

JEL Classification Code : M10, M40, M41

\section{Introduction}

Economic transformation in Vietnam has been a key driver for development of the economy and businesses. In the process of integration with international accounting, Vietnam enterprises have gradually applied contemporary accounting practices, in line with market-oriented mechanisms. Over

\footnotetext{
*Acknowledgements: The authors would like to thank anonymous referees for their constructive comments on the earlier version of this paper.

${ }^{1}$ First Author and Corresponding Author. Lecturer, Head, Department of Accounting and Auditing, Thuongmai University, Vietnam [Postal Address: 79 Ho Tung Mau Street, Cau Giay District, Hanoi, 122868, Vietnam] Email: hieu.pd@tmu.edu.vn

2Lecturer, Department of Economics, Hung Yen University of Technology and Education, Vietnam. Email: daohuongkt84@gmail.com

${ }^{3}$ Lecturer, Department of Economics, Viettri University of Industry, Vietnam. Email: dungbuitien102@gmail.com

(c) Copyright: The Author(s)

This is an Open Access article distributed under the terms of the Creative Commons Attribution Non-Commercial License (http://Creativecommons.org/licenses/by-nc/4.0/) which permits unrestricted noncommercial use, distribution, and reproduction in any medium, provided the original work is properly cited.
}

the past decade, since it has been officially recognized in the Accounting Law 2003 and in the Circular 53/2006/TT-BTC, management accounting (MA) in Vietnam has experienced remarkable development. MA has been designed as a separate module in the accounting curriculums in many universities around the country. However, compared to other countries in the world or/and in the region, MA in Vietnam is still considered as an appendix of financial accounting (Adams \& Do, 2005). In fact, there exists a significant gap in research on management accounting practices (MAPs) in enterprises in Vietnam compared to other developing countries and transitional economies like India, China, Thailand, and Malaysia.

This study aims to examine the existing level of MAPs and the contingency factors that impact MAPs in manufacturing enterprises in the north of Vietnam by conducting a quantitative survey. For these purposes, two research questions will be addressed:

Research question 1: What is the current level of MAPs in manufacturing enterprises in Vietnam?

Research question 2: What are the contingency factors that impact the current level of MAPs in Vietnam's manufacturing enterprises? 
Research results will be compared to the framework on the development of MAPs proposed by IFAC (1998) and Nishimura (2003) with the aims of determining the current level of MAPs in Vietnam. The main objectives of this study are also to find and evaluate the impact of internal and external contingency factors on MAPs and to establish the MAPs undertaken by the manufacturing companies in Vietnam. This study is useful as regards practical, theoretical and managerial respects. It will contribute to the current management accounting literature in two important ways. First, it will provide new empirical evidence using MAPs. Second, it will facilitate studies in a new context of Vietnam in regard to how contingency factors affect the use of MAPs.

The paper is structured as follows. The next section briefly presents the theoretical framework, literature review and research hypotheses. The third section presents the methods and surveyed sample. The fourth section analyzes and interprets the research results. The fifth section ends the paper with conclusion and recommendations.

\section{Literature Review}

\subsection{Framework for the Development of MAPs}

\subsubsection{The IFAC 1998 Framework}

According to IFAC (1998), MAPs have gone through four different stages of development:

Stage 1 (before 1950): focused on cost and financial control. Therefore, MAPs were quite limited and not really independent, separated from financial accounting.

Stage 2 (1950-1965): placed on decision-making assistance by several techniques, such as standard costing, CVP analysis, and responsibility accounting. Hence, MA has been away from the shadow of financial accounting.

Stage 3 (1965-1985): focused on reduction of waste of resources by extensive use of mathematical models, typically, multivariate regression models and EOQ model.

Stage 4 (from 1985): centred on creation of value through effective resource utilisation, characterized by the emerging techniques like customer profitability analysis, shareholder value added analysis, JIT, BSC, and strategic management accounting.

\subsubsection{Nishimura 2003 Framework}

Nishimura (2003) describes the development of MAPs as a four-stage framework as follows:

Stage 1 (Drifting): no independent system of management accounting in this stage. The main focus is applications of financial accounting information to management and control purposes. MAPs widely adopted are financial ratio and trend analysis.
Stage 2 (Traditional): MAPs, namely, budgeting, standard costing, CVP analysis, responsibility accounting, and cost variance analysis are dominantly used in this stage. MAPs in this stage still have deep influences on current MA. Therefore, it is named as 'traditional' MA.

Stage 3 (Quantitative information): concentrated on how to optimize profit-based management. MAPs are dominated by models such as profit prediction, linear regression, opportunity cost analysis, and relevant information analysis.

Stage 4 (Integrated): MAPs are integrated with organizational management, strategic management, and feed-forward concept. Therefore, techniques widely adopted in this stage are lean production management, target costing, kaizen costing, activity-base management, balanced scorecard, value chain analysis, life cycle analysis, quality costing system, JIT, TQM, and so on.

Fundamentally, Nishimura (2003) model is consistent with IFAC (1998) model in terms of dividing the development of management accounting into four stages. It can be seen from both frameworks that the degree of sophistication increases stage by stage and MA functions are enhanced period after period. In this study, we use both IFAC (1998) and Nishimura (2003) models as the main theoretical framework when assessing the development of MAPs in Vietnam.

\subsection{Literature Review and Research Hypotheses}

\subsubsection{Research on Management Accounting Practices}

Along with the development of MA, many studies on MAPs have been done recently in both developing and in transitional economies (Joshi, 2001; Nishimura, 2002).

Sulaiman, Ahmad and Alwi (2004) studied MAPs in four Asian countries: Malaysia, Singapore, China, and India. The authors found that most contemporary techniques were not applicable, while traditional techniques were assessed as 'very useful'. Ghosh and Chan (1997), in a study on MAPs in Singapore, have found that many different techniques of MA are applied. However, new techniques like TQM and ABC have very limited use. In 2002, Chan conducted another study for the purpose of examining the development of MAPs in Singapore. The findings showed no significant changes in MAPs in the country since 1997. Nishimura (2002) studied Japanese firms in Singapore, Malaysia and Thailand and shows that MAPs in these countries are in transition between the initial phase (Stage 1) and traditional phase (Stage 2). Nishimura (2002) found that the advanced techniques of MA have not been applied in Japanese companies operating in the three surveyed countries.

Over time, recent studies on MAPs in developing countries in the Asian region such as Ahmad (2012) in Malaysia, Huang, Lai, Kao and Chen (2012) in China, and Sumkaew, Liu and McLaren (2014) in Thailand showed the same results that businesses mostly rely on traditional techniques of MA 
because they are easy to apply. However, due to the impact of current business environment, several contemporary techniques of MA also attracted attention of managers, and many of them said that they would apply the new ones in future when conditions permitted. However, the authors mentioned above agree that in general MAPs in developing and in transitional economies in Asia are only in Stage 1 and 2 of IFAC (1998) or Nishimura (2003) framework.

As mentioned earlier, since transforming into a marketbased economy, MA and MAPs in Vietnam have progressed significantly. Many studies on MA have been conducted for the last ten years. However, these studies mainly focus on implementing approach, applying one or some specific methods of MA in certain industries or sectors, such as pharmaceutical industry, agriculture, construction, and food processing (Pham, 2007; Nguyen, 2011; Nguyen, 2013). The research on assessing the application of MA in enterprises in Vietnam, and comparison with other countries in the region is almost absent, except for a limited number of studies (Doan, 2012; Nguyen, 2013; Pham \& Bui, 2018). Therefore, there is a need for additional studies to narrow the research gap on the level of MAPs in Vietnamese enterprises and to clarify the impact of contingency factors that affect the current application of MAPs in the country.

\subsubsection{Framework of Analysis}

Concerning the factors affecting the adoption of MAPs, the literature shows that the differences in the application of management accounting techniques among organizations can be explained by the many contingency factors, which include internal and external (Amara \& Benelifa, 2017). Many researchers claim that traditional management accounting is no longer adequate for the modern business environment, since the business environment and production conditions have changed dramatically (Johnson \& Kaplan, 1987; Nishimura, 2003; Shahzadi, Khan, \& Toor, 2018). These changes encourage the application of modern management accounting techniques in order to provide relevant and timely information to assist management in making better decisions. Contingency theory claims that there is not a single most ideal approach to control organizations, which would generally apply to all organizations consistently and in all conditions (Otley, 1980). Therefore, there is no universally satisfactory model of organizations that describes the variety of organized designs, that is why organization designs rest on contingency factors suited to the situation (Shahzadi, Khan, \& Toor, 2018). The contingency approach to management accounting is based on the premise that there is no universally appropriate accounting system, which applies equally to all organizations in all circumstances (Otley, 1980). This theory suggests that particular features of an appropriate accounting system will depend upon the specific circumstances in which an organization finds itself (Otley, 1980).

To answer the second research question, this study takes into account several fundamental contingency factors and examines their impacts on the current MAPs in Vietnam's

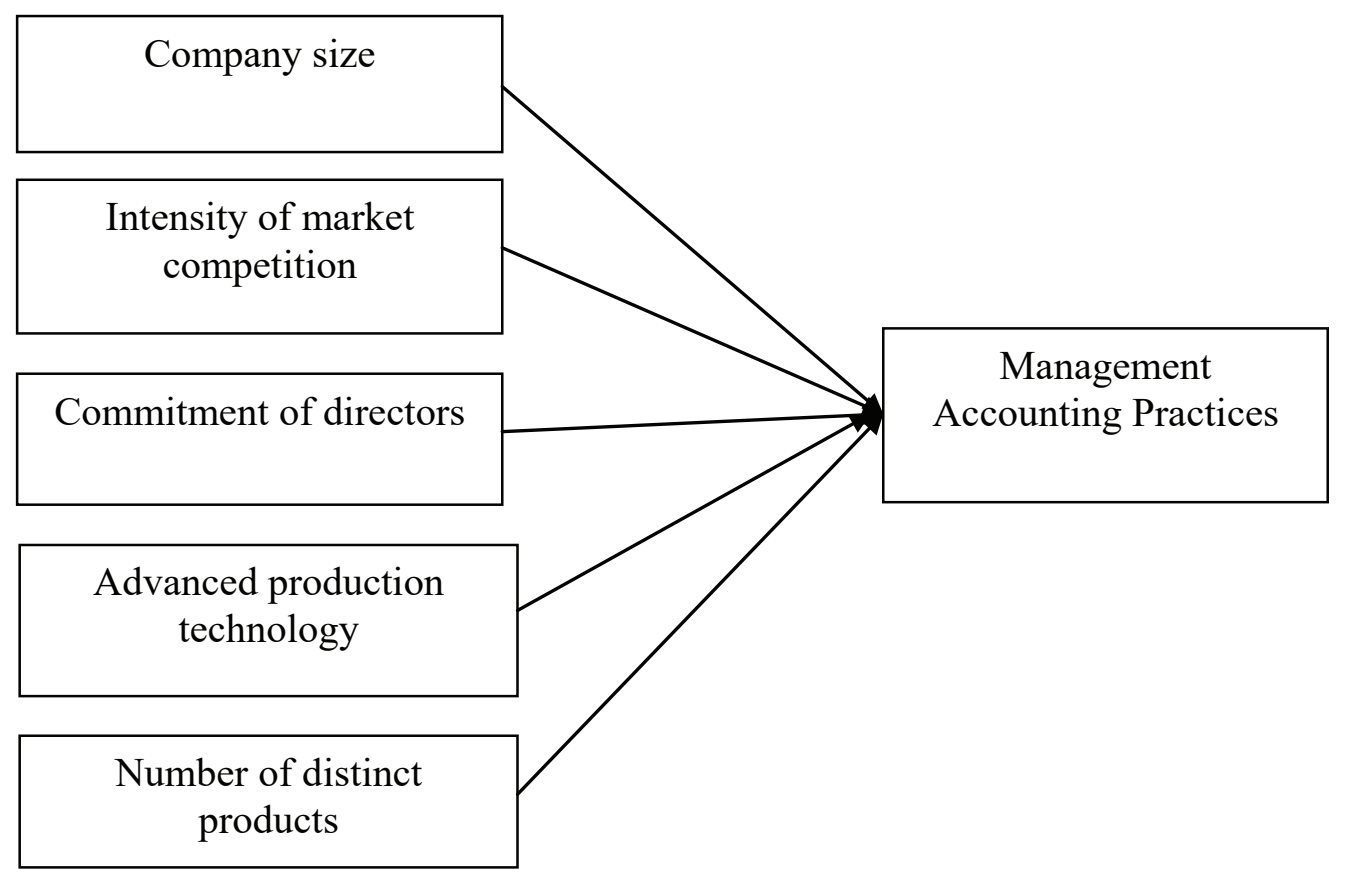

Figure 1: The framework of analysis 
manufacturing companies. Relied on the suggestions from previous studies (Ahmad, 2012; Huang, Lai, Kao, \& Chen, 2012; Sumkaew, Liu, \& McLaren, 2014; Shahzadi, Khan, \& Toor, 2018; Nguyen, 2020; Nguyen, 2020; Truong, Nguyen, \& Duong, 2020) the selected contingency factors are company size, intensity of market competition, commitment of directors, advanced production technology, and number of distinct products.

The framework presented below shows the impact of contingency factors on MAPs in Vietnam's manufacturing firms.

Therefore, the following hypotheses are generated:

H1: There is a significant positive relationship between company size and management accounting practices in Vietnam's manufacturing firms.

H2: There is a significant positive relationship between intensity of market competition and management accounting practices in Vietnam's manufacturing firms.

H3: There is a significant positive relationship between commitment of directors and management accounting practices in Vietnam's manufacturing firms.

H4: There is a significant positive relationship between advanced production technology and management accounting practices in Vietnam's manufacturing firms.

H5: There is a significant positive relationship between distinct number of products and management accounting practices in Vietnam's manufacturing firms.

\section{Research Methodology}

Data were collected by questionnaires with manufacturing enterprises in the north of Vietnam. The target respondents are both accountants and CEOs. The first part of the questionnaire will be answered by CEOs; meanwhile, the second part will be filled out by accountants. The combination of two kinds of respondents on the same answer sheet will encourage the double check, hence, resulting in a more objective and general view when evaluating the current level of MAPs in the surveyed company. Moreover, this combination also reduces bias data, thus, eliminating the likelihood of unmatched data if two questionnaires are used separately for the accountants and for the CEOs. The questionnaire utilized a five-item scale for the variables in study that was adopted from Ahmad (2012) and Sumkaew, Liu and McLaren (2014). The data from the study was computed using SPSS 22.0 software.

The Multivariable regression model is used to analyze the contingency factors affecting MAPs in Vietnam as follows:

$$
\begin{aligned}
\text { MAPS }= & \beta_{0}+\beta_{1} S I Z E+\beta_{2} C O M P+\beta_{3} M G T+ \\
& \beta_{4} T E C H+\beta_{5} P R D+\varepsilon
\end{aligned}
$$

Where: MAPs $=$ Management Accounting Practices, SIZE = Company size, $\mathrm{COMP}=$ Intensity of market competition, $\mathrm{MGT}=$ Commitment of directors, $\mathrm{TECH}=$ Advanced production technology, $\mathrm{PRD}=$ Distinct number of products, $\beta \mathrm{i}=$ coefficient, and $\varepsilon=$ error. The detail of variables and their references are as follow (Table 1):

In total, there are 300 distributed questionnaires between June 2019 and September 2019; the collected number is 180 , thus, a rate of $61.7 \%$. After removing the missing data, 160 questionnaires (corresponding to 160 companies $(53.3 \%)$ can be useable for statistical analysis. General information of companies in the survey can be seen in the Table 2 below.

Table 1: Research variables

\begin{tabular}{|l|c|l|c|c|}
\hline \multicolumn{1}{|c|}{ Variables } & $\begin{array}{c}\text { Nature of } \\
\text { variable }\end{array}$ & Measurement & $\begin{array}{c}\text { No. of } \\
\text { questions }\end{array}$ & References \\
\hline $\begin{array}{l}\text { Management Accounting practices } \\
\text { (MAPs) }\end{array}$ & Dependent & Questionnaire & 48 & $\begin{array}{c}\text { Ahmad (2012), Doan (2012), Nguyen } \\
\text { (2013) }\end{array}$ \\
\hline Company size (SIZE) & Independent & Questionnaire & 3 & $\begin{array}{c}\text { Ahmad (2012); Abdel-Kader and } \\
\text { Luther (2008) }\end{array}$ \\
\hline $\begin{array}{l}\text { Intensity of market competition } \\
\text { (COMP) }\end{array}$ & Independent & Questionnaire & 4 & $\begin{array}{c}\text { Ahmad (2012); Doan (2012); Abdel- } \\
\text { Kader and Luther (2008) }\end{array}$ \\
\hline Commitment of directors (MGT) & Independent & Questionnaire & 3 & Ahmad (2012) \\
\hline $\begin{array}{l}\text { Advanced production technology } \\
\text { (TECH) }\end{array}$ & Independent & Questionnaire & 3 & $\begin{array}{c}\text { Ahmad (2012); Abdel-Kader and } \\
\text { Luther (2008) }\end{array}$ \\
\hline Distinct number of products (PRD) & Independent & Questionnaire & 3 & $\begin{array}{c}\text { Abdel-Kader and Luther (2008), } \\
\text { Chongruksut and Brooks (2005) }\end{array}$ \\
\hline
\end{tabular}


Table 2: General information of enterprises in the study

\begin{tabular}{|l|c|c|}
\hline \multicolumn{1}{|c|}{ Classification } & Number & $\begin{array}{c}\text { Per cent } \\
\text { (\%) }\end{array}$ \\
\hline Respondents & & \\
\hline Managers & 32 & 20.0 \\
\hline Chief accountants & 46 & 28.7 \\
\hline Accountants & 82 & 51.3 \\
\hline Total & 160 & 100.0 \\
\hline Respondents' working experience & & \\
\hline Below 10 years & 34 & 21.3 \\
\hline From 10 to 15 years & 66 & 41.2 \\
\hline Above 15 years & 60 & 37.5 \\
\hline Total & 160 & 100.0 \\
\hline Number of employees & & \\
\hline Below 300 & 0 & 0 \\
\hline From 300 to 500 & 117 & 73.1 \\
\hline Above 500 & 43 & 26.9 \\
\hline Total & 160 & 100.0 \\
\hline
\end{tabular}

\section{Data Analysis and Discussion}

\subsection{Current Management Accounting Practices (MAPs) in Vietnam}

The empirical results on MAPs in the studied enterprises are presented in Table 3 by sequential mean values that based on the Likert scales with $1=$ rarely used and $5=$ frequently used.

The two last columns of Table 3 identify different stages of MAPs in studied enterprises. As can be seen, the techniques of Stages 1 and 2 as classified by IFAC (1998) and Nishimura (2003) are most applied, accounting for 32 out of 48 techniques, $(66.7 \%)$. This finding suggests that traditional MAPs are dominated in manufacturing enterprises in Vietnam. Thus, it can be concluded that MA in Vietnam has reached a full development of Stage 2 - the traditional stage.

For Stages 3 and 4 of MAPs, the data show that the applications are still at a moderate and low level. However, positive points can be recognized when 16 contemporary techniques of Stage 4 are selected by studied enterprises. A notable difference is that quantitative methods of Stage

Table 3: Current status of Management Accounting Practice (MAPs) in Vietnam

\begin{tabular}{|c|l|c|c|c|}
\hline \multirow{2}{*}{ Order } & \multicolumn{1}{|c|}{ MAPs } & \multirow{2}{*}{ Mean } & \multicolumn{2}{c|}{ Development stage } \\
\cline { 4 - 5 } & & & IFAC (1998) & Nishimura (2003) \\
\hline 1 & Performance evaluation: Operating income & 3.8125 & 1 & 1 \\
\hline 2 & Performance evaluation: Sales growth & 3.8033 & 1 & 1 \\
\hline 3 & Performance evaluation: ROI & 3.6349 & 2 & 2 \\
\hline 4 & Costing technique: Full cost & 3.5556 & 1 & 2 \\
\hline 5 & Strategic costing & 3.4839 & 4 & 4 \\
\hline 6 & Performance evaluation: Variance analysis & 3.4355 & 2 & 2 \\
\hline 7 & Performance evaluation: On time delivery & 3.4333 & 4 & 2 \\
\hline 8 & Annual budget & 3.4082 & 2 & 4 \\
\hline 9 & Customers' satisfaction & 3.4000 & 4 & 2 \\
\hline 10 & Direct material budget & 3.3878 & 2 & 2 \\
\hline 11 & Direct labour budget & 3.3725 & 2 & 2 \\
\hline 12 & Production budget & 3.3725 & 2 & 4 \\
\hline 13 & Supply demand \& market analysis & 3.3667 & 4 & 2 \\
\hline 14 & Overhead cost budget & 3.3542 & 2 & 2 \\
\hline 15 & Customer profitability analysis & 3.3415 & 2 & 2 \\
\hline 16 & Time pay back & 3.3171 & 2 & 2 \\
\hline 17 & Performance evaluation: Cash flows & 3.2833 & 2 & 2 \\
\hline 18 & Monthly budget & 3.2800 & 2 & 2 \\
\hline 19 & Process costing & 3.2373 & 2 & \\
\hline
\end{tabular}




\begin{tabular}{|c|c|c|c|c|}
\hline 20 & Target costing & 3.2333 & 4 & 4 \\
\hline 21 & Performance evaluation: Gross profit ratio & 3.2250 & 1 & 1 \\
\hline 22 & Product profitability analysis & 3.1860 & 4 & 4 \\
\hline 23 & Sales budget & 3.1538 & 2 & 2 \\
\hline 24 & Purchasing budget & 3.1379 & 2 & 2 \\
\hline 25 & Life-cycle costing & 3.1333 & 4 & 4 \\
\hline 26 & Value chain analysis & 3.1290 & 4 & 4 \\
\hline 27 & Inventory controls & 3.1136 & 4 & 4 \\
\hline 28 & Decision making assistance: IRR & 3.0732 & 2 & 2 \\
\hline 29 & Batch costing & 3.0667 & 1 & 2 \\
\hline 30 & Job order costing & 3.0656 & 1 & 2 \\
\hline 31 & Non-manufacturing cost budget & 3.0545 & 2 & 2 \\
\hline 32 & Performance evaluation: sales/direct labour & 2.9818 & 4 & 4 \\
\hline 33 & Financial position budget & 2.9818 & 2 & 2 \\
\hline 34 & Defect rate & 2.9818 & 4 & 4 \\
\hline 35 & Decision making assistance: NPV & 2.9750 & 2 & 2 \\
\hline 36 & Incremental budgeting & 2.9556 & 2 & 2 \\
\hline 37 & Performance evaluation: absentee rates & 2.9310 & 4 & 4 \\
\hline 38 & Performance evaluation: lead time & 2.9138 & 4 & 4 \\
\hline 39 & Decision making assistance: BEP analysis & 2.9048 & 2 & 2 \\
\hline 40 & Contract costing & 2.8475 & 1 & 2 \\
\hline 41 & Budget for planning cash flows & 2.7692 & 2 & 2 \\
\hline 42 & Fixed budgeting & 2.7556 & 2 & 2 \\
\hline 43 & Number of customer complains & 2.6949 & 4 & 4 \\
\hline 44 & Flexible budgeting & 2.6667 & 2 & 2 \\
\hline 45 & Absorption costing & 2.5439 & 1 & 2 \\
\hline 46 & Activity based costing & 2.4912 & 4 & 4 \\
\hline 47 & Variable costing & 2.2105 & 1 & 2 \\
\hline 48 & Zero based budgeting & 2.0000 & 4 & 4 \\
\hline
\end{tabular}

3 are not highly appreciated by Vietnamese enterprises. The selection of advanced MAPs in Stage 4 is partly explained by the uncertainty of the current business environment, and by the level of deeper integration of Vietnam's economy.

\subsection{Impact of Contingency Factors on MAPs in Vietnam}

\subsubsection{Pearson Correlation}

Pearson correlation test was used to examine the correlation between each of independent variables with the dependent variable. The results of the correlation test show company size is 0.574 , intensity of market competition is 0.583 , commitment of directors is 0.733 , advanced production technology is 0.689 , and distinct number of products is 0.674 . The results indicate that company size and intensity of market competition have a moderate positive correlation with MAPs, while commitment of directors, advanced production technology, and distinct number of products have a fairly high positive correlation with MAPs (Table 4).

\subsubsection{Multiple Regression Analysis}

Multiple regression analysis was done to test the variables in the research with the aim of testing the hypotheses. Multiple regression analysis examines the regression coefficients for each of the independent variables and dependent variable. Durbin-Watson in this research is 1.786 
that is within the required range of 1 to 3 , indicating that there is no autocorrelation among residuals. This means the data collected in the study shows that there is no inter-item correlation. In addition, the result of $\mathrm{R}$ Square is 0.621 or $62.1 \%$. This indicates that $62.1 \%$ of the total variance in the dependent variable is explained by the independent variables. Table 5 presents the result of multiple regression analysis.

The result of coefficients shows that the relationships between company size, commitment of directors, advanced production technology, and distinct number of products and MAPs are positive and highly significant. These findings confirm the empirical results of previous studies such as Abdel-Kader and Luther (2008), Chongruksut and Brooks (2005), and Ahmad (2012). However, the positive relationship between distinct number of products and MAPs contradicts
Abdel-Kader and Luther (2008) who found no significant difference of complexity of processing system among four MAP sophistication levels. Additionally, the relationship between intensity of market competition and MAPs is insignificant with significant value of 0.165 greater than 0.05 . This finding confirms the empirical results of previous studies of Abdel-Kader and Luther (2008), Amara and Benelifa (2017) and Shahzadi, Khan and Toor (2018) that explained that there is no significant difference between the extent of use of MAPs among companies in terms of the intensity of competition in the market. On the other hand, it is in contradiction with Doan (2012) who found the positive correlation between competition and MAPs. Our result implies that the improvement in MAPs is not explained by the intensity of market competition (Shahzadi, Khan, \& Toor, 2018).

Table 4: Pearson correlation test

\begin{tabular}{|c|c|c|c|c|c|c|c|}
\hline \multicolumn{2}{|c|}{} & MAPs & SIZE & COMP & MGT & TECH & PRD \\
\hline \multirow{3}{*}{ MAPs } & Pearson Correlation & 1 & $.574^{* *}$ & $.583^{* *}$ & $.733^{* *}$ & $.689^{* *}$ & $.674^{* *}$ \\
\cline { 2 - 8 } & Sig. (2-tailed) & & .000 & .000 & .000 & .000 & .000 \\
\cline { 2 - 8 } & $\mathrm{N}$ & 160 & 160 & 160 & 160 & 160 & 160 \\
\hline
\end{tabular}

**. Correlation is significant at the 0.01 level (2-tailed).

Table 5: Multiple regression analysis

\begin{tabular}{|c|c|c|c|c|c|c|c|}
\hline & \multicolumn{2}{|c|}{$\begin{array}{l}\text { Unstandardized } \\
\text { Coefficients }\end{array}$} & \multirow{2}{*}{$\begin{array}{c}\begin{array}{c}\text { Standardized } \\
\text { Coefficients }\end{array} \\
\text { Beta }\end{array}$} & \multirow[b]{2}{*}{$\mathbf{t}$} & \multirow[b]{2}{*}{ Sig. } & \multicolumn{2}{|c|}{ Collinearity Statistics } \\
\hline & B & Std. Error & & & & Tolerance & VIF \\
\hline (Constant) & .629 & .218 & & 2.881 & .005 & & \\
\hline SIZE & .102 & .057 & .124 & 1.788 & .016 & .550 & 1.817 \\
\hline COMP & .092 & .066 & .104 & 1.397 & .165 & .480 & 1.084 \\
\hline MGT & .314 & .084 & .333 & 3.764 & .000 & .339 & 1.950 \\
\hline TECH & .169 & .083 & .178 & 2.036 & .044 & .345 & 1.897 \\
\hline PRD & .186 & .088 & .182 & 2.128 & .035 & .361 & 1.774 \\
\hline
\end{tabular}

Table 6: Summary of the hypothesis testing results

\begin{tabular}{|c|c|c|c|c|}
\hline & Hypothesis & Significant & Result & Beta $(\beta)$ \\
\hline $\mathrm{H} 1$ & $\begin{array}{l}\text { There is a significant positive relationship between company size and } \\
\text { management accounting practices in Vietnam's manufacturing firms }\end{array}$ & .016 & Accepted & .124 \\
\hline $\mathrm{H} 2$ & $\begin{array}{l}\text { There is a significant positive relationship between intensity of market competition } \\
\text { and management accounting practices in Vietnam's manufacturing firms }\end{array}$ & .165 & Rejected & .104 \\
\hline $\mathrm{H} 3$ & $\begin{array}{l}\text { There is a significant positive relationship between commitment of directors and } \\
\text { management accounting practices in Vietnam's manufacturing firms }\end{array}$ & .000 & Accepted & .333 \\
\hline $\mathrm{H} 4$ & $\begin{array}{l}\text { There is a significant positive relationship between advanced production technology } \\
\text { and management accounting practices in Vietnam's manufacturing firms }\end{array}$ & .044 & Accepted & .178 \\
\hline H5 & $\begin{array}{l}\text { There is a significant positive relationship between distinct number of products } \\
\text { and management accounting practices in Vietnam's manufacturing firms }\end{array}$ & .035 & Accepted & .182 \\
\hline
\end{tabular}


Based on the analysis, the hypotheses on the positive relationship between company size, advanced production technology, commitment of directors, and distinct number of products and MAPs are accepted, while the hypothesis on the relationship between intensity of market competition and MAPs is rejected. Table 6 presents the summary of the hypotheses testing results.

\section{Conclusion and Recommendations}

\subsection{Conclusion}

The findings of this study generate an overall picture of MAPs in manufacturing enterprises in Vietnam after more than a 15-year application since MA officially recognized in the country in 2003. Our main findings are: (i) MAPs in Vietnam are in Stage 2 of development as the same level in other countries in the region (Malaysia, Thailand, and China). However, MAPs in Vietnam are in the transition phase towards contemporary MAPs, although at relatively low levels. These findings are inconsistent with the conclusions of Nishimura (2002) and Doan (2012), but consistent with Nguyen's findings (2013); (ii) MAPs in Vietnam are mainly affected by company size, commitment of directors, advanced manufacturing technology, and distinct number of products rather than intensity of competition from the emerging market.

\subsection{Recommendations}

The results from this study convey an important message to various parties, such as the policymakers, the government, and professional bodies that policies and practical guidelines have to be installed and implemented in a synchronized way to improve MAPs in Vietnam. In order to promote the contemporary MAPs, several recommendations are proposed: (i) Renew and update the accounting curriculums, textbooks and other learning materials of MA in universities and colleges in Vietnam; (ii) Create the better linkages between information demands of management and information supplied by accounting system in enterprise along with the development in company size, production technology, and distinct number of products; (iii) Step by step, help managements get familiar with contemporary MAPs such as target costing, $\mathrm{ABC}$, BSC, value chain analysis; and (iv) Extensively rely on modern and available enterprise management software that will assist MAPs transformation from traditional and short-term orientations to contemporary and long-term strategies.

The present study cannot avoid some embedded limitations. The results are limited to manufacturing enterprises, therefore, they cannot be generalized to other fields. Moreover, because of limited investigation in the north of Vietnam, the findings cannot be representing the whole country. In the future, research comprising various business sectors in different provinces will enable the authors to generate deeper conclusions on the level of MAPs and the impact of factors on MAPs in Vietnamese enterprises.

\section{References}

Abdel-Kader, M., \& Luther, R. (2008). The impact of firm characteristics on management accounting practices: a UKbased empirical analysis. The British Accounting Review, 40(2), 2-17. http://dx.doi.org/10.1016/j.bar.2007.11.003

Adams, H. A., \& Do, T. L. (2005). VNGAAP and VNGAAS: convergence to international accounting and auditing principles. Hanoi: National Political Publisher.

Ahmad, K. (2012). The use of management accounting practices in Malaysian SMEs. Doctoral dissertation. Exeter, UK: University of Exeter.

Amara, T., \& Benelifa, S. (2017). The impact of external and internal factors on the management accounting practices. International Journal of Finance and Accounting, 6(2), 46-58. DOI: $10.5923 /$ j.ijfa.20170602.02

Chan, Y. K. (2002). Management Accounting Practice in Singapore. A paper presented at the Asian Management Accounting Forum. Fukuoka, Japan, November 1-4.

Chongruksut, W., \& Brooks, A. (2005). The Adoption and Implementation of Activity-Based Costing in Thailand. Asian Review of Accounting, 13(2), 1-17. https://doi.org/10.1108/ eb060784

Doan, N. P. (2012). The adoption of Western management accounting practices in Vietnamese enterprises during economic transition. Doctoral dissertation. Queensland, Australia: Griffith University.

Ghosh, B. C., \& Chan, Y. K. (1997). Management accounting in Singapore-well in place. Managerial Auditing Journal, 12(1), 16-18. https://doi.org/10.1108/02686909710155966

Huang, H., Lai, M. C., Kao, M., \& Chen, Y. (2012). Target costing, Business model innovation, and firm performance: an empirical analysis of Chinese firms. Canadian Journal of Administrative Sciences, 29(4), 322-335. https://doi.org/10.1002/cjas.1229

International Federation of Accountants (IFAC). (1998). International Management Accounting Practice Statement: Management Accounting Concepts. New York: Financial and Management Accounting Committee.

Johnson, T. H., \& Kaplan, R. S. (1987). Relevance Lost: The Rise and Fall of Management Accounting. Boston, MA: Havard Business School Press.

Joshi, P. L. (2001). The International Diffusion of New Management Accounting Practices: The case of India. Journal of International Accounting, Auditing and Taxation, 10(1), 85109. https://doi.org/10.1016/S1061-9518(01)00037-4

Nguyen, N. T. (2020). Factors Affecting Responsibility Accounting at Public Universities: Evidence from Vietnam. Journal of 
Asian Finance, Economics and Business, 7(4), 275-286. https:// doi.org/10.13106/jafeb.2020.vol7.no4.275

Nguyen, Q. T. (2011). Cost Management Accounting in Agricultural Enterprises in Vietnam. Doctoral dissertation. Hanoi, Vietnam: National Economics University.

Nguyen, T. M. (2013). Responsibility Accounting in Milk Processing enterprises in Vietnam. Doctoral dissertation. Hanoi, Vietnam: National Economics University.

Nguyen, T. P. (2013). The evoluation of management accounting practices in Vietnam: empirical evidence from vietnamese food and beverage enterprises. Doctoral dissertation. Sendai, Japan: Tohoku University.

Nguyen, T. K. T. (2020). Studying Factors Affecting Environmental Accounting Implementation in Mining Enterprises in Vietnam. Journal of Asian Finance, Economics and Business, 7(5), 131144. https://doi.org/10.13106/jafeb.2020.vol7.no5.131

Nishimura, A. (2002). Management Accounting Practice of Japanese Affiliates in Singapore, Thailand and Malaysia. A paper presented at the Asian Management Accounting Forum. Fukuoka, Japan, November 1-4.

Nishimura, A. (2003). Management Accounting: Feed forward and Asian perspectives. New York, NY: Palgrave Macmillan.

Otley, D. T. (1980). The contingency theory of management accounting: Achievement and prognosis. Accounting Organizations and Society, 5(4), 413-428. https://doi. org/10.1016/0361-3682(80)90040-9
Pham, D. H., \& Bui, T. D. (2018). Management Accounting Practices in Vietnam: An Empirical Study. Account and Financial Management Journal, 3(7), 1616-1620. DOI:10.31142/afmj/ v3i7.02

Pham, T. T. (2007). Modeling Cost Management Accounting for Pharmaceutical enterprises in Vietnam. Doctoral dissertation. Hanoi, Vietnam: National Economics University.

Shahzadi, S., Khan, R., \& Toor, M. (2018). Impact of external and internal factors on management accounting practices: a study of Pakistan. Asian Journal of Accounting Research, 3(2), 211-223. DOI:10.1108/AJAR-08-2018-0023

Sulaiman, M., Ahmad, N., \& Alwi, N. (2004). Management accounting practices in selected Asian countries: a review of the literature. Managerial Auditing Journal, 9(4), 493-508. https://doi.org/10.1108/02686900410530501

Sumkaew, N., Liu, Y. J., \& McLaren, J. (2014). Management Accounting Practices in Thailand. Bristish Accounting \& Finance Association (BAFA) Annual Conference. London School of Economics, London, UK, April 14-16.

Truong, D. D., Nguyen, H., \& Duong, T. L. (2020). Factors Influencing Balanced Scorecard Application in Evaluating the Performance of Tourist Firms. Journal of Asian Finance, Economics and Business, 7(5), 217-224. https://doi. org/10.13106/jafeb.2020.vol7.no5.217 